\title{
Seasonal study of grazing by metazoan zooplankton in the mesohaline Chesapeake Bay
}

\author{
Jacques R. White*, Michael R. Roman
}

Horn Point Environmental Laboratory, Center for Environmental and Estuarine Studies, The University of Maryland System, PO Box 775, Cambridge, Maryland 21613, USA

\begin{abstract}
Grazing of phytoplankton by the metazoan zooplankton community was measured on 5 dates from March to August 1987, and 4 dates from March to October 1988 at a single station in the mesohaline Chesapeake Bay, USA. In situ grazing measurements were made on several taxa including copepod nauplii and meroplanktonic larvae. Zooplankton grazing was dominated by Acartia species copepods in March and August, polychaete larvae in May, and the cyclopoid copepod Oithona colcarva in June 1987 and October 1988. Copepod nauplii were nearly always important grazers because of their relatively high biomass and weight-specific ingestion rates. The amount of daily phytoplankton production removed by zooplankton in 1988 varied between 12 and $103 \%$, with March $>$ August > October > May
\end{abstract}

\section{INTRODUCTION}

Metazoan zooplankton are potentially important consumers of phytoplankton biomass in coastal and estuarine systems, especially when the phytoplankton is dominated by large cells. However, few seasonal studies have actually measured in situ grazing rates of zooplankton feeding on natural particle assemblages, together with distribution and abundance measurements for the same organisms.

Previous studies in the marine environment which have measured grazing rates of zooplankton in situ have done so on the basis of zooplankton size, but have failed to distinguish between relative amounts of material ingested by different species (Bishop et al. 1986) or by early developmental stages of dominant species (Dagg \& Turner 1982, Nicolajsen et al. 1983, Stearns et al. 1987, Tiselius 1988). The lack of information on feeding by meroplanktonic larvae which can be abundant in estuaries is especially conspicuous (Strathmann 1987, Young \& Chia 1987).

The Chesapeake Bay provides a suitable environ-

\footnotetext{
- Present address: Smithsonian Environmental Research Center, Smithsonian Institution, POBox 28, Edgewater, Maryland 21037, USA
}

ment to examine zooplankton community grazing since species diversity is relatively low and seasonal transitions between dominant organisms are fairly clear. The bay is characterized by large seasonal changes in temperature, salinity, nutrient input, dissolved oxygen, primary production, and the abundance of predators. As a result, zooplankton populations change throughout the year with different species becoming dominant under different conditions in the mesohaline portion of the bay. During the winter months, the dominant zooplankton species are the calanoid copepods Acartia hudsonica followed in time by Eurytemora affinis. From May to October A. tonsa becomes the dominant species with Oithona colcarva usually present and abundant at times (Heinle 1966. Brownlee \& Jacobs 1987, Olson 1987). Periodically, meroplanktonic species such as polychaete, barnacle, and bivalve larvae dominate the zooplankton (Brownlee \& Jacobs 1987, Olson 1987). The microzooplankton (20 to $200 \mu \mathrm{m}$ ) are generally dominated by protozoa and rotifers but copepod nauplii can be the most abundant members during March and August (44 $\mu \mathrm{m}$ net samples; Brownlee \& Jacobs 1987).

Seasonal phytoplankton dynamics in the bay follow a general pattern of low production and standing stock in early winter, a late winter-spring diatom bloom (or 
series of small bloomlets), high productivity and fluctuating standing stocks of phyto-flagellates during summer, and another smaller diatom bloom in the fall (Malone et al. 1988)

The amount of phytoplankton standing stock utilized by zooplankton in Chesapeake Bay is of interest for at least 2 reasons. First, phytoplankton biomass that is not grazed by zooplankton sinks directly into bottom waters where it decomposes, contributing to anoxia during summer (Malone et al. 1988). Second, conversion of phytoplankton to zooplankton biomass (especially as copepod nauplii) makes primary production available to higher trophic levels. In this study, we have attempted to measure the grazing impact on phytoplankton by dominant species and developmental stages of the metazoan zooplankton community over 2 successive spring-summer (and fall in 1988) seasons in the mesohaline Chesapeake Bay.

\section{METHODS}

Location. Samples were collected and experiments run at one 20 meter deep station in mid-channel of the mesohaline Chesapeake Bay $\left(31^{\circ} 40^{\prime} \mathrm{N}, 64^{\circ} 15^{\prime} \mathrm{W}\right)$. Five $24 \mathrm{~h}$ stations were occupied in the first year of the study: March 12, May 12, June 4, and August 14 and 20, 1987; and 4 during the second year: March 24, May 19, August 31 and October 20, 1988.

Productivity and hydrographic property measurements. Temperature, salinity and chl a depth profiles ( $1 \mathrm{~m}$ intervals) were determined using a pump with inline sensors for conductivity, temperature and fluorescence (Malone \& Ducklow 1990). In order to convert in vivo fluorescence to chlorophyll, samples were collected from the surface and $1 \mathrm{~m}$ above the bottom in $5 \mathrm{I}$ Niskin bottles and analyzed by fluorometer after acetone extraction (Parsons et al. 1984). Primary production was measured by shipboard incubation of sea water with ${ }^{14} \mathrm{C}$-bicarbonate in light and dark bottles (Malone \& Ducklow 1990).

Zooplankton biomass. Samples were collected for species abundance and biomass every $3 \mathrm{~h}$ during the diel stations. A hose system pumped water 20 to $40 \mathrm{I} \mathrm{min}^{-1}$ ) through $64 \mu \mathrm{m}$ mesh nets in containers on deck from 3 depths: below, through, and above the pycnocline. Samples were preserved in $5 \%$ formalin and counted and measured in the laboratory using a microscope, digitizing pad and computer imageanalysis system. Pump avoidance by adult and later stage copepods estimated by making vertical net tows for zooplankton in the surface layer with a $0.5 \mathrm{~m}$ diameter, $200 \mu \mathrm{m}$ mesh net simultaneously with pump samples was not significant (paired sample $t$-test, $p>0.05$. $\mathrm{n}=8$ ). Algorithms for length-to-weight relationships
Table 1 Empirically determined algorithms used in image analysis system to convert length $\left(L, \mathrm{~mm}\right.$ ind.$\left.^{-1}\right)$ of different taxa to dry weight ( $W, \mu g$ ind $\left.^{-1}\right)$ along with regression statistics. Carbon $\left(\mu \mathrm{g} \mathrm{C}\right.$ in. $\left.\mathrm{d}^{-1}\right)=0.32 \mathrm{~W}$

\begin{tabular}{|lcccc|}
\hline Taxa & $\mathrm{r}^{2}$ & Equation & $b$ & $\mathrm{SE}_{b}$ \\
\hline $\begin{array}{l}\text { Copepod and } \\
\text { barnacle nauplii }\end{array}$ & 0.97 & $W=15.53 L^{b}$ & 2.17 & 0.268 \\
Oithona colcarva & 0.90 & $W=7.509 L^{b}$ & 1.36 & 0.160 \\
Acartia spp. & 0.64 & $W=9.501 L^{b}$ & 1.55 & 0.399 \\
General copepods & 0.97 & $W=15.5 L^{b}$ & 2.17 & 0.268 \\
Polychaete larvae & 0.67 & $W=63.82 L^{b}$ & 1.81 & 0.398 \\
Cladoceran & 0.94 & $W=16.78 L^{b}$ & 2.97 & 0.173 \\
\hline
\end{tabular}

(Table 1) were determined for each species empirically by drying and weighing individuals of different lengths on a Cahn Electrobalance, and correcting for $30 \%$ shrinkage due to preservation with formalin. Carbon was assumed to be $32 \%$ of corrected dry weight (Wiebe et al. 1975). Data for both surface and deep samples are the average over $24 \mathrm{~h}$.

Grazing rates. Zooplankton grazing of phytoplankton was measured using the radio-labeled compounds ${ }^{3} \mathrm{H}$-methylamine $\left({ }^{3} \mathrm{H}-\mathrm{MeA}\right)$ and ${ }^{14} \mathrm{C}$-bicarbonate in both 51 in situ chambers (Roman \& Rublee 1981) and 1 I shipboard bottles (Daro 1978). In general, incubation times were kept short to reduce cycling of label from phytoplankton through protozoa to larger zooplankton. During 1987, in situ chambers were incubated with ${ }^{14} \mathrm{C}$-bicarbonate at 1 to $2 \mathrm{~m}$ depth in daylight for 50 to $60 \mathrm{~min}$. For shipboard experiments, phytoplankton were prelabelled for $1 \mathrm{~h}$ under fluorescent light with ${ }^{14} \mathrm{C}$-bicarbonate before adding copepods (Daro 1980, Roman et al. 1988a). Zooplankton were collected from the surface layer by oblique tows with a $0.5 \mathrm{~m}$ diameter, $64 \mu \mathrm{m}$ mesh net fitted with a closed cod end. The catch was diluted and unsorted zooplankton were gently transferred into polycarbonate bottles filled with surface water (20 to 100 ind. $\mathrm{I}^{-1}$ ). Once copepods were added, the bottles were placed in light (day) or dark (night) incubators with flowing bay water for 15 to $60 \mathrm{~min}$.

For in situ experiments in 1988, a combination of ${ }^{3} \mathrm{H}-\mathrm{MeA}$ and ${ }^{14} \mathrm{C}$-bicarbonate was added in daylight, surface incubations while ${ }^{3} \mathrm{H}-\mathrm{MeA}$ alone was used for dark incubations 19 to $15 \mathrm{~m}$ in the chlorophyll maximum and nighttime). ${ }^{3} \mathrm{H}$-methylamine is an ammonium analog transported into phytoplankton in both light and dark (Balch 1985) which gives grazing rates similar to those obtained using ${ }^{14} \mathrm{C}$-bicarbonate (White \& Roman 1991). This method allows in situ experiments to be run at night, at depth below the photic zone, and eliminates the need to expose phytoplankton cells to intense light before dark shipboard incubations. 
For both procedures, zooplankton were separated from particulate matter using 64 and $200 \mu \mathrm{m}$ Nitex screens, washed with filtered $(0.22 \mu \mathrm{m})$ bay water (FBW) and anesthetized in a $\mathrm{CO}_{2}$-FBW solution. Individuals from the 2 size fractions were separated into taxonomic and developmental groups, transferred by pipet onto preweighed $12.0 \mu \mathrm{m}$ polycarbonate (PC) filters, and rinsed with $10 \% \mathrm{HCl}$ followed by distilled water to remove adsorbed label and salt respectively. Filters were then dried at $60^{\circ} \mathrm{C}$, weighed and analyzed for radioactivity. Particulate matter passing the $64 \mu \mathrm{m}$ screen was collected on $3.0 \mu \mathrm{m}$ PC filters, acidified in vials with $35 \mu \mathrm{l}$ glacial acetic acid, and the activity analyzed by liquid scintillation counting. We chose to estimate 'available' particulate matter using a $3.0 \mu \mathrm{m}$ filter because capture efficiency of zooplankton is less than $50 \%$ for smaller particle sizes (Nival \& Nival 1976, Bartram 1980, Berggreen et al. 1988).

Clearance rate $\left(F=\mathrm{ml}\right.$ ind $\left.\mathrm{r}^{-1} \mathrm{~h}^{-1}\right)$ was calculated using the equations of Daro (1978) and represents the volume of water cleared per individual per unit time. Weight-specific carbon ingestion rate $[I=\mu \mathrm{g}$ phytoplankton $\mathrm{C}$ ( $\mathrm{mg}$ copepod $\mathrm{C})^{-1} \mathrm{~h}^{-1}$ ] was obtained by multiplying $F$ by phytoplankton carbon and dividing by animal carbon ( $\mu \mathrm{g} \mathrm{C}$ ind.$^{-1}$ ). Phytoplankton carbon was estimated from the in situ carbon-to-chlorophyll ratio of samples taken throughout the study period $\left(\mathrm{C}=51\right.$ chl $\left.a, \mathrm{n}=13, \mathrm{r}^{2}=0.48, \mathrm{SE}= \pm 16\right)$. For this calculation, we assume that the $y$-intercept represents non-phytoplankton carbon and that this value varies independently of phytoplankton carbon.

Grazing rate represents the amount of phytoplankton carbon removed by feeding zooplankton in a given volume or integrated area of the water column, and has units analogous to primary production (i.e. $\mu \mathrm{g} \mathrm{C} \mathrm{m} \mathrm{m}^{-3} \mathrm{~h}^{-1}$ or $\mathrm{mg} \mathrm{C} \mathrm{m}^{-2} \mathrm{~d}^{-1}$ ). Grazing rates were obtained by multiplying the weight-specific ingestion rate by the biomass concentration (or the biomass integrated above and below the pycnocline).

For abundant taxa (i.e. copepod nauplii and Acartia copepodites), data presented for biomass, ingestion and grazing rates are averages of at least 1 night and 2 day measurements for each parameter, usually taken at 07:00, 13:00 and 24:00 h. For less abundant species, only 1 or 2 daily measurements of feeding rate may have been made. Because of this relatively low temporal sampling resolution, we did not attempt to assess night/day differences in feeding by zooplankton. Rather, averaging over all sample periods we hoped to account for some of the potential variation occurring within sample dates caused by diel differences in feeding intensity (Boyd et al. 1980, Dagg \& Grill 1980, Dagg 1985, Stearns 1986, Roman et al. 1988a).

\section{RESULTS}

\section{Biomass and species composition}

Total zooplankton biomass was highest in March and October 1988 (214.4 and $90.3 \mathrm{mg} \mathrm{C} \mathrm{m}^{-3}$ respectively). due principally to the occurrence of large copepod stocks below the pycnocline (Fig. 1). Acartia spp. (A. hudsonica in early spring, $A$. tonsa at other times) usually accounted for most of the copepod biomass in samples with Eurytemora affinis occurring occasionally in March 1988 and May of both years (Fig. 1). The small cyclopoid copepods Oithona colcarva and Saphirella spp. were sporadically present from May to August, while $O$. colcarva was present in large numbers at depth during October 1988 (Fig. 1). Rotifers were present during March and October 1988. In May of both years and June 1987, polychaete larvae swarmed the water column and dominated the biomass, especially below the pycnocline (Fig. 1). Between years, total biomass was lower in 1987 vs 1988 for March (29.2 vs $214.4 \mathrm{mg} \mathrm{C} \mathrm{m}^{-3}$ ) and May (28.3 vs $48.1 \mathrm{mg} \mathrm{C} \mathrm{m}^{-3}$ ) cruises, and higher for the average of the 2 cruises in August 1987 vs 1988 (42.5 vs $28.6 \mathrm{mg} \mathrm{C} \mathrm{m}^{-3}$ ).

\section{Clearance and ingestion rates}

The highest weight-specific carbon ingestion rates were observed for most groups during August of both years (Fig. 2). Rates were very low for all species in May of 1987, but high for nauplii, polychaetes, and cladocerans in May 1988. Values of individual filtration and carbon-specific ingestion rates averaged over the study are shown in Table 2 . In general, filtration rates increased with increasing temperature ffor Acartia copepodites: $F=F_{\max }\left(1-\mathrm{e}^{-k T}\right)$ where $k=0.009 ; \mathrm{n}=16, \mathrm{r}^{2}=0.43$, $p<0.001$; least squares estimate of best fit for MarquardtLevenberg iterative algorithm, Statgraphics version 2.0] and increasing body size (Table 2). On the other hand, carbon-specific ingestion by copepods increased with increasing temperature [for Acartia copepodites: $I=$ $I_{\max }\left(1-\mathrm{e}^{-k T}\right)$ where $\left.k=0.011 ; \mathrm{n}=16, \mathrm{r}^{2}=0.29, \mathrm{p}<0.001\right]$ but decreased with increasing body size, with the highest rates occurring for Acartia nauplii, Oithona colcarva, and Saphirella spp., and the lowest rates for adult Acartia and Eurytemora copepodites (Table 2). Polychaete larvae had the highest filtration and ingestion rates of the noncopepod species, which otherwise had relatively low rates (Table 2).

\section{Grazing rate}

The largest amount of grazing pressure exerted by any group occurred in August 1987 when nauplii in sur- 

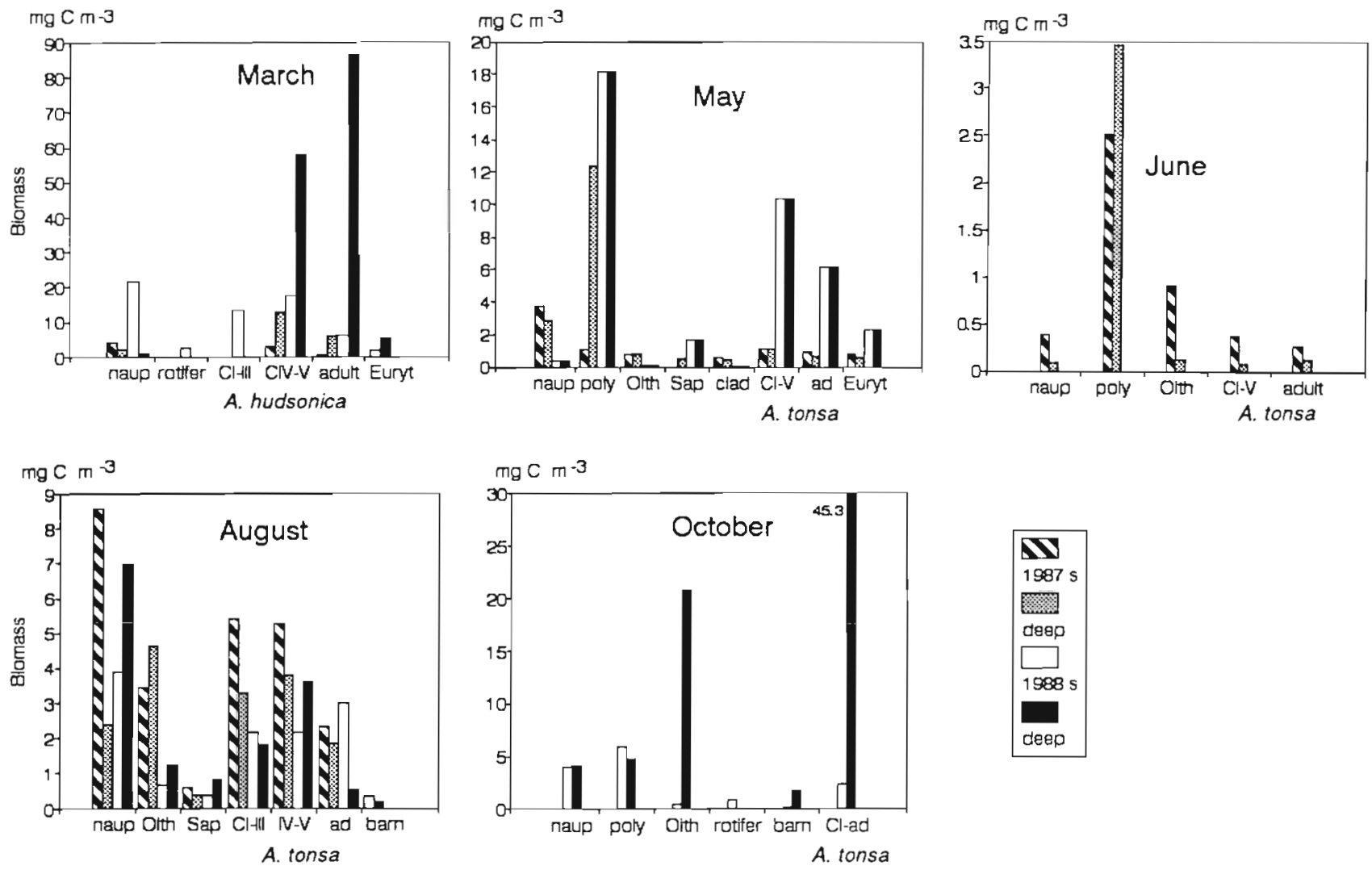

Fig. 1. Biomass of zooplankton species and developmental stages (> $64 \mu \mathrm{m}$ ) collected above and below pycnocline in Chesapeake Bay for different months in 1987 and 1988. Values are averages of 1 afternoon, midnight, and morning samples for each date. Note difference in vertical scales. Abbreviations for taxonomic groups are: naup = copepod nauplii, $C(I-V)=c o p e p o d i d$ stage, Euryt = Eurytemora sp., poly = polychaete larvae, Oith = Oithona sp., Sap = Sapirella sp., clad = cladoceran, ad $=$ adult, barn = barnacle nauplii

face waters cleared nearly $2 \mathrm{mg} \mathrm{C} \mathrm{m}^{-3} \mathrm{~h}^{-1}$ (Fig. 3). Since grazing rate is a function of both biomass and ingestion rate, the large biomass of Acartia hudsonica adults and copepodites occurring at depth in March 1988 resulted in grazing rates in excess of $1 \mathrm{mg} \mathrm{C} \mathrm{m}^{-3} \mathrm{~h}^{-1}$ (Fig. 3). Because of their large biomass, polychaetes had high grazing rates in May $1988\left(0.8 \mathrm{mg} \mathrm{C} \mathrm{m}^{-3} \mathrm{~h}^{-1}\right)$, while low ingestion rates resulted in low grazing rates 10.02 to $0.04 \mathrm{mg} \mathrm{C} \mathrm{m}^{-3} \mathrm{~h}^{-3}$ ) by the A. tonsa population at that time (Fig. 3). Oithona colcarva were the dominant grazers during June 1987, and important again in October 1988 along with $A$. tonsa copepodites. For the entire study period, nauplii had consistently high grazing rates compared to other groups (Fig. 3) due to their relatively high abundance and ingestion rates.

Since we measured feeding in both surface and deep water only during 1988, we used data from that year to compare zooplankton grazing with production and standing stock of phytoplankton at our Chesapeake Bay station. Grazing by the zooplankton community integrated over the entire water column could remove between 12 (May) and $103 \%$ (March) of the daily primary production occurring at the study site (Table 3). Turnover time $(t)$, the time required for phytoplankton production to replace standing stock, was similar to estimates of removal time $(r)$, the time required for grazers to remove phytoplankton stocks, only in March. In May, $t$ was roughly a factor of 0.1 shorter duration than $r$, indicating a removal mechanism other than metazoan grazing.

Grazing by nauplii consistently accounted for a substantial percentage of the total depth-integrated grazing, peaking at $50 \%$ during the August cruise (Fig. 4). The highest grazing pressure exerted by any taxonomic group in our study occurred in March 1988 when Acartia hudsonica copepodites accounted for $75 \%$ of total grazing (Fig. 4 ) and removed roughly the same percentage of the local primary production (Table 3). During May, when only $12 \%$ of the primary production was removed by metazoan zooplankton (Table 3), grazing was dominated by polychaete larvae (Fig. 4).

\section{Variance of measurements}

In order to evaluate variance in the suite of measurements made for this study, feeding rate and biomass 

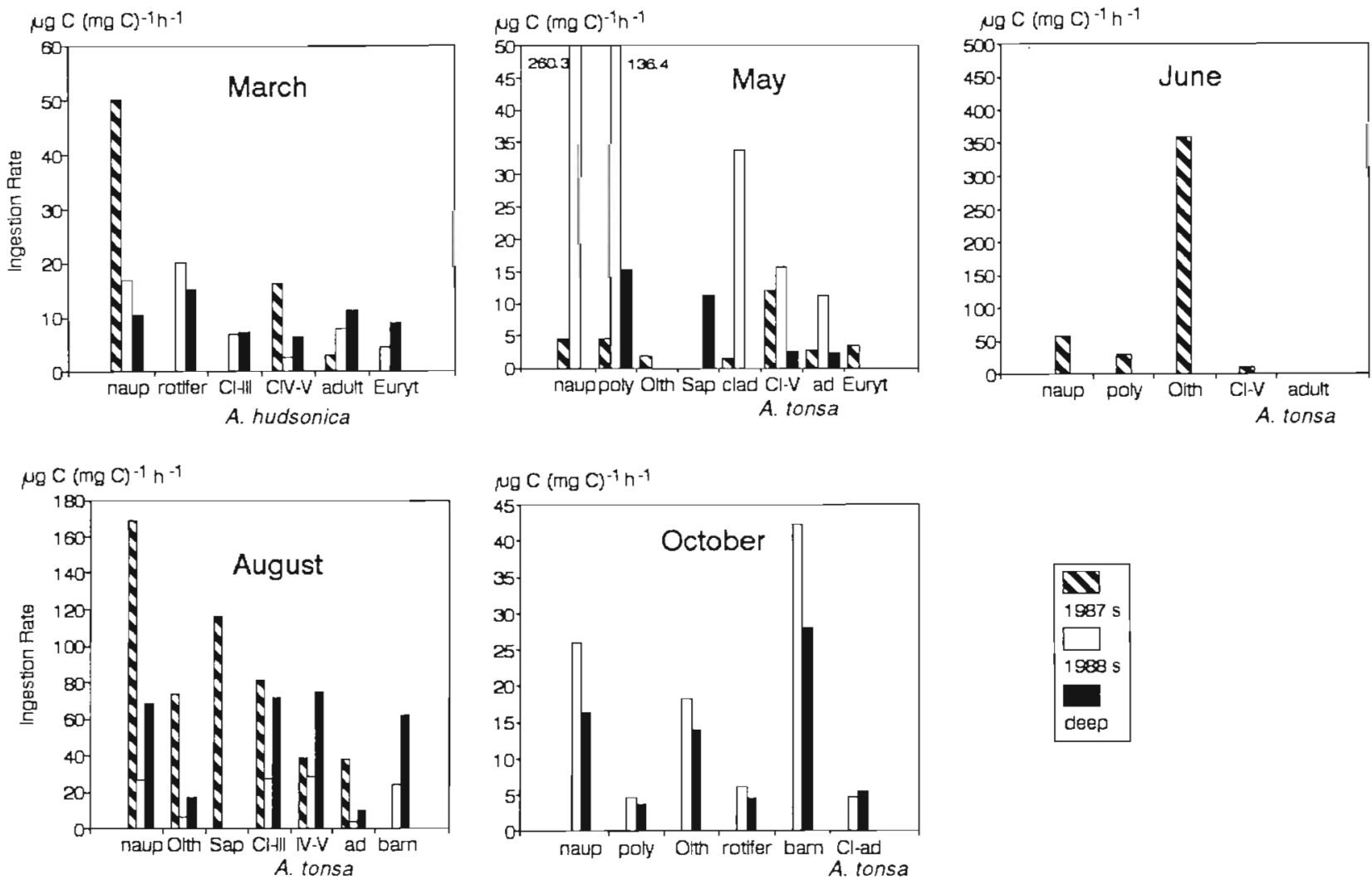

Fig. 2. Ingestion rates on phytoplankton measured shipboard (1987) and in situ (1987-88) for zooplankton in Chesapeake Bay. Note difference in vertical scales. Abbreviations as in Fig. 1

Table 2. Study-wide averages $( \pm S E)$ of daily individual clearance $(F)$ and carbon-specific ingestion $(I)$ rates for different species and developmental stages of metazoan zooplankton $(>64 \mu \mathrm{m})$ collected from Chesapeake Bay. W: dry weight; n: no. of measurements; $T$ : temperature range

\begin{tabular}{|c|c|c|c|c|c|c|}
\hline & Species & $\begin{array}{c}F \\
\left(\mathrm{ml} \mathrm{ind}^{-1} \mathrm{~d}^{-1}\right)\end{array}$ & $\stackrel{I}{\left(\mu \mathrm{g} \mathrm{C}(\mu \mathrm{g} \text { bodyC })^{-1} \mathrm{~d}^{-1}\right)}$ & $\mathrm{n}$ & $\begin{array}{c}W \\
\left(\mu \text { ind }^{-1}\right)\end{array}$ & $\begin{array}{c}T \\
\left({ }^{\circ} \mathrm{C}\right)\end{array}$ \\
\hline \multirow[t]{5}{*}{ Copepods } & $\begin{array}{l}\text { Acartia hudsonica } \\
\text { Nauplii } \\
\text { Stage CI-III } \\
\text { Stage CIV-V } \\
\text { Stage CVI (adult) }\end{array}$ & $\begin{array}{l}0.47(0.27) \\
0.23(0.09) \\
0.29(0.11) \\
1.32(0.27)\end{array}$ & $\begin{array}{l}0.79(0.38) \\
0.10(0.02) \\
0.22(0.17) \\
0.11(0.02)\end{array}$ & $\begin{array}{l}5 \\
4 \\
6 \\
9\end{array}$ & $\begin{array}{r}0.5 \\
1.2 \\
4.0 \\
10.0\end{array}$ & $4-7$ \\
\hline & $\begin{array}{l}\text { Acartia tonsa } \\
\text { Nauplii } \\
\text { Stage CI-III } \\
\text { Stage CIV-V } \\
\text { Stage CVI (adult) }\end{array}$ & $\begin{array}{l}1.99(0.50) \\
2.85(0.79) \\
2.19(0.64) \\
7.19(5.02)\end{array}$ & $\begin{array}{l}2.80(0.91) \\
1.83(0.64) \\
0.96(0.32) \\
0.58(0.22)\end{array}$ & $\begin{array}{l}21 \\
20 \\
26 \\
19\end{array}$ & $\begin{array}{l}0.31 \\
1.4 \\
4.0 \\
8.0\end{array}$ & $15-26$ \\
\hline & $\begin{array}{c}\text { Eurytemora affinis } \\
\text { Stage CIl to V }\end{array}$ & $1.5(0.45)$ & $0.08(0.02)$ & 4 & 8.1 & $4-15$ \\
\hline & $\begin{array}{l}\text { Oithona colcarva } \\
\text { Stage CIII-VI (adult) }\end{array}$ & $4.1(1.15)$ & $1.42(0.33)$ & 20 & 0.35 & $15-26$ \\
\hline & Saphirella spp. & $3.1(1.9)$ & $2.26(1.29)$ & 6 & 2.8 & $15-26$ \\
\hline Other plankton & $\begin{array}{l}\text { Polychaete larvae } \\
\text { Cladoceran } \\
\text { Rotifer } \\
\text { Barnacle }\end{array}$ & $\begin{array}{l}5.6(4.43) \\
0.57(0.48) \\
0.55(0.17) \\
1.19\end{array}$ & $\begin{array}{l}1.29(0.78) \\
0.42(0.36) \\
0.37(0.11) \\
0.95\end{array}$ & $\begin{array}{l}10 \\
5 \\
4 \\
2\end{array}$ & $\begin{array}{l}1.3 \\
1.2 \\
1.2 \\
2.8\end{array}$ & $\begin{array}{r}15-23 \\
15-17 \\
4-15 \\
15-17\end{array}$ \\
\hline
\end{tabular}



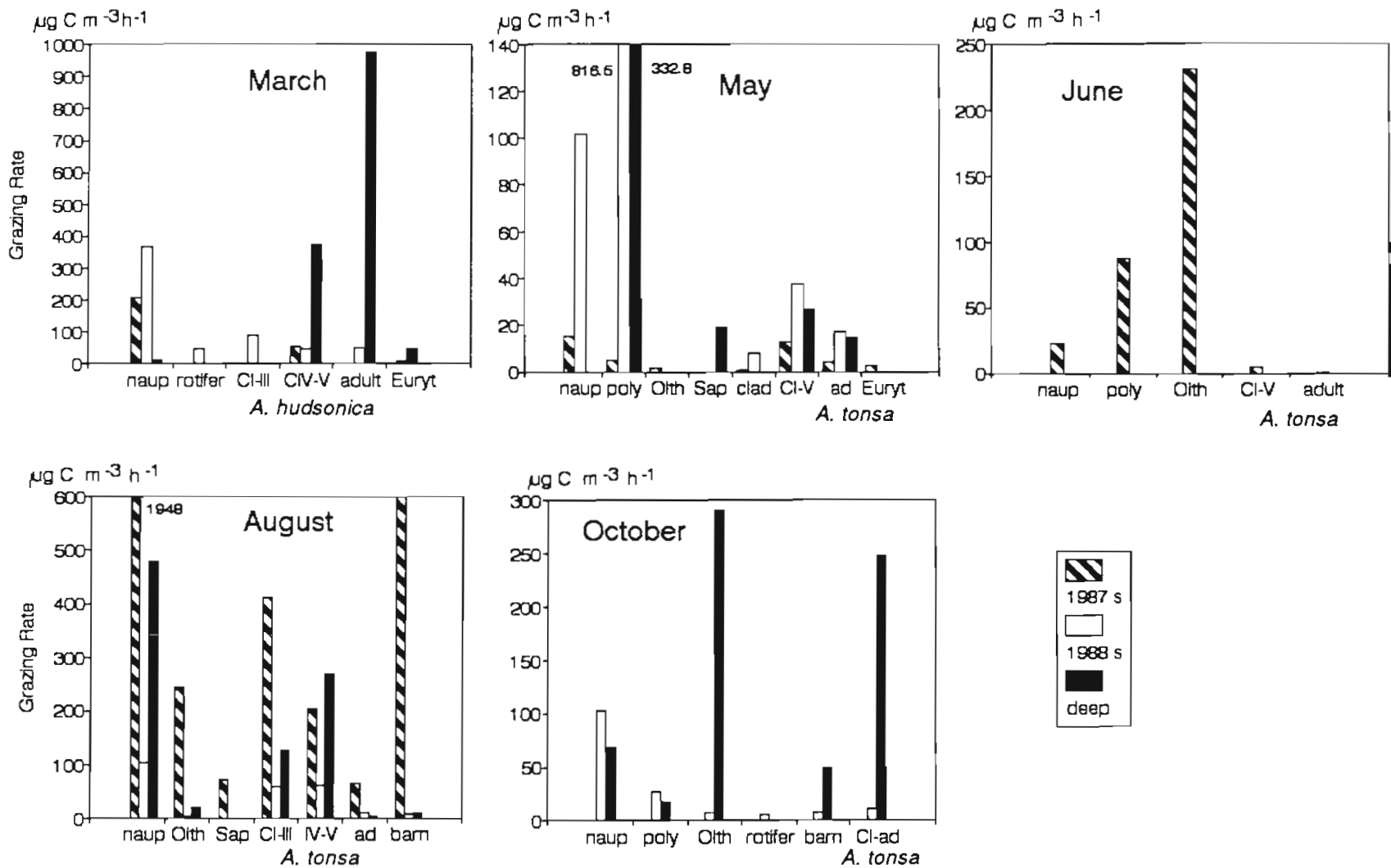

Fig. 3. Grazing rates (ingestion $\times$ biomass) by zooplankton on phytoplankton in Chesapeake Bay for different months in 1987 and 1988. Note difference in vertical scales. Abbreviations same as in Fig. 1

measurements for Acartia copepodites along with temperature and chlorophyll data collected from the mixed surface layer were analyzed for variation within and between sample dates in March, May, and August, and between years. There was no significant difference between similar sampling dates for years 1987 and 1988 in any of the measurements (ANOVA, $p>0.05$ ). Therefore, meas-

Table 3. Depth-integrated phytoplankton standing stock $(S=$ $51 \mathrm{chl}$ a), primary production $(P)$, metazoan zooplankton grazing $(G)$, and the percentage production grazed by zooplankton $(\% P)$ determined from 4 cruises to a station in the mesohaline Chesapeake Bay during 1988. Turnover time $t=$ $S / P$ ) is an estimate of time required to replace phytoplankton stock if local production is only source. Removal time $(r=\mathrm{S} / G)$ is the time required to remove phytoplankton stock if grazing is only loss term

\begin{tabular}{|lrrrr|}
\hline & Mar & \multicolumn{1}{c}{ May } & Aug 3 & \multicolumn{1}{c|}{ Oct } \\
& $24-25$ & $19-20$ & -Sep 1 & $19-20$ \\
\hline$\left.S(\mathrm{mg} \mathrm{C} \mathrm{m})^{-2}\right)$ & 9246 & 23138 & 4677 & 3935 \\
$\left.P(\mathrm{mg} \mathrm{C} \mathrm{m})^{-2} \mathrm{~d}^{-1}\right)$ & 440 & 1868 & 999 & 1046 \\
$G\left(\mathrm{mg} \mathrm{C} \mathrm{m} \mathrm{d}^{-1}\right)$ & 451 & 231 & 439 & 213 \\
$\% P$ & 103 & 12 & 44 & 20 \\
$t(\mathrm{~d})$ & 21 & 12 & 5 & 4 \\
$r(\mathrm{~d})$ & 20 & 100 & 11 & 18 \\
\hline
\end{tabular}

ured parameters from similar dates were pooled for the 2 years (i.e. May 1987 with May 1988). Results of 1-way ANOVA (Table 4) show that for temperature, and filtration and ingestion rates, within-sample-date variation was not sufficient $(p<0.05)$ to obscure significant differences between sample dates (months). For chlorophyll, zooplankton biomass, and grazing, within-sample-date variation precluded significant differences between dates. The highest variation occurred in biomass and grazing rate data ( 30 and $45 \%$ of mean values respectively)

\section{DISCUSSION}

We found, as others have (Brownlee \& Jacobs 1987 Olson 1987), that zooplankton in the mesohaline Chesapeake Bay are dominated by copepods of the genus Acartia during the early spring, late summer, and fall, followed in importance by Oithona colcarva in late summer and fall. Our observations on the 2 Acartia species were consistent with those of Conover (1956), who argued that the seasonal distribution of $A$. clausi (now hudsonica) is limited by high summer temperatures while that of $A$. tonsa is limited by low food abundance during winter in Long Island Sound, USA. 
March 24-25, 1988

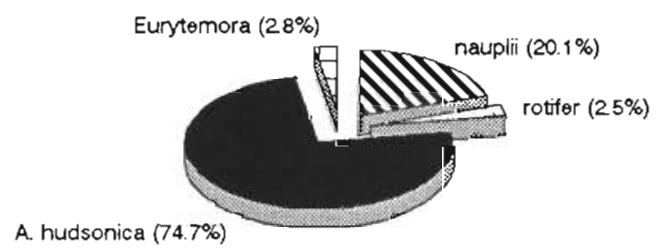

total grazing: $451 \mathrm{mg} \mathrm{C} \mathrm{m}^{-2} \mathrm{~d}^{-1}$

May $19-20,1988$

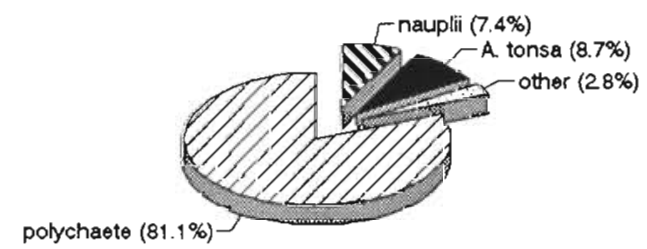

total grazing: $231 \mathrm{mg} \mathrm{C} \mathrm{m}-2 \mathrm{~d}^{-1}$

August 31- Sept. 1, 1988

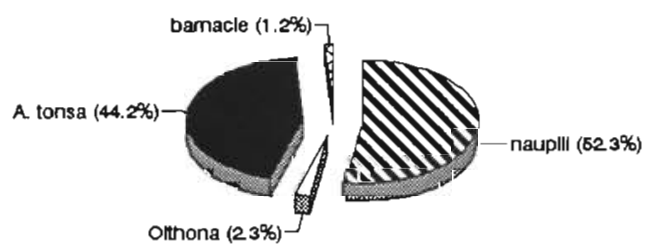

total grazing: $439 \mathrm{mg} \mathrm{C} \mathrm{m}^{-2} \mathrm{~d}^{-1}$

\section{October 19-20, 1988}

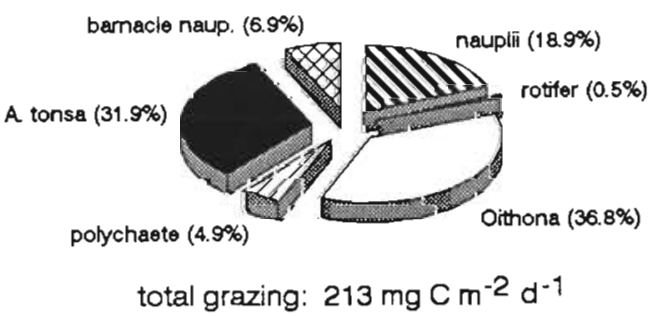

Fig. 4. Partitioning of grazing by the zooplankton community integrated over the water column in Chesapeake Bay for several dates in 1988. Pie areas show percents of total grazing.

Magnitude of total grazing is given below each diagram

The exception to copepod dominance of biomass occurs in late spring-early summer, when copepod populations are reduced and polychaete larvae enter the water column in great numbers. Starr et al. (1990) noted that sea urchin and mussel spawning seem closely coupled with phytoplankton blooms, and
Lacalli (1981) has found that planktonic polychaete larvae are restricted to periods of the spring bloom increase in Passamaquoddy Bay, New Brunswick, Canada. Chlorophyll a concentrations are elevated (10 to $30 \mu \mathrm{g} \mathrm{l}^{-1}$ ) in deep waters of Chesapeake Bay during May (Malone et al. 1988), and it is possible that settlement of the spring diatom bloom to the benthos triggers release of gametes by adult worms

Many studies (Conover 1956, Heinle 1969, Ikeda 1974, Banse 1982, and others) have shown that metabolic processes in zooplankton are related to temperature. So it is not surprising that ingestion and filtration rate generally increased with temperature in our study (Fig. 2, Table 2). Conover showed that filtration rates are higher for Acartia clausi (now hudsonica) than $A$. tonsa at a given temperature. However, the 2 species did not co-occur much during sampling periods and all stages of the summer distributed $A$. tonsa had higher average feeding rates than $A$. hudsonica.

The average specific ingestion rate obtained for Acartia tonsa nauplii during our study (280\% body C $\mathrm{d}^{-1}$ ) was high compared to maximum laboratory values of 100 to $150 \%$, obtained at $15^{\circ} \mathrm{C}$ for Calanus pacificus nauplii (Fernández 1979), and $130 \%$ for $A$. tonsa adults feeding at $17^{\circ} \mathrm{C}$ (Berggreen et al. 1988). These literature values were recorded in the low end of the temperature range $\left(15\right.$ to $\left.26^{\circ} \mathrm{C}\right)$ experienced by A. tonsa in the bay, and the discrepancies may be the result of increased respiration and carbon demand at elevated temperature in situ.

The average specific ingestion rate of $58 \%$ measured for Acartia tonsa adults was lower than the maximum value obtained by Berggreen et al. (1988), but well in the range of specific rates $(<0.1$ to $152 \%)$ measured for $A$. tonsa adults occurring in the Mississippi river plume (Tester \& Turner 1988). Paffenhöfer (1971) found that specific daily ingestion rate decreased from $292-481 \%$ for nauplii to $28-85 \%$ for adult female Calanus helgolandicus (now pacificus), similar to the trend in our results for Acartia. The lower weightspecific rate of phytoplankton ingestion by later stage copepods compared to juveniles in our study may reflect a decreased metabolic rate with age, or may indicate an additional source of nutrition in adults such as microzooplankton (Stoecker \& Egloff 1987, Gifford \& Dagg 1988, White \& Roman 1992) or detritus (Heinle \& Flemer 1975, Roman 1984). For their large size $\left(\right.$ mean $=8 \mu \mathrm{g}$ dry wt ind ${ }^{-1}$ ), Eurytemora affinis copepodites and adults had low clearance rates $(1.5 \mathrm{ml}$ ind ${ }^{-1} \mathrm{~d}^{-1}$ ) and the lowest carbon-specific ingestion rates measured during our study $(8 \%)$. In contrast, Barthal (1983) found a value of $212 \%$ at $15^{\circ} \mathrm{C}$. Salinity ranged from 10 to $20 \%$ at our study site, near the tolerance limit of $E$. affinis, and may have accounted in part for their low feeding rates (Olson 1987). 
Table 4. Results of 1 -way analysis of variance comparing surface mixed-layer data between sampling dates in March, May, and August pooled for years 1987 and 1988. Shown are sample size (n), the overall mean, \pm standard error (SE), SE as percent of mean (\% ERR), F-ratio for ANOVA between dates, and significance level (SL); "significant difference, and '"highly significant difference. T: temperature; Chl: chlorophyll $>3.0 \mu \mathrm{m}_{\text {; }}$ and for Acartia tonsa copepodites, F: filtration rate; $l$ : ingestion rate; $B$ : biomass; $G$ : grazing rate

\begin{tabular}{|c|c|c|c|c|c|c|}
\hline Parameter & $\mathrm{n}$ & Mean & SE & $\% \mathrm{ERR}$ & F-ratio & SL \\
\hline$T\left({ }^{\circ} \mathrm{C}\right)$ & 15 & 17.91 & 0.32 & 2 & $\cdots 330.511$ & $<0.001$ \\
\hline $\operatorname{Chl}\left(\mu \mathrm{g}^{-1}\right)$ & 17 & 6.77 & 0.79 & 12 & 0.296 & 0.748 \\
\hline$F\left(\mathrm{ml}\right.$ ind $\left.\mathrm{h}^{-1}\right)$ & 16 & 0.07 & 0.01 & 15 & $\cdots 6.866$ & 0.009 \\
\hline$I\left[\mu \mathrm{g} \mathrm{C}(\mathrm{mg} \text { bodyC })^{-1} \mathrm{~h}^{-1}\right]$ & 16 & 15.89 & 3.56 & 22 & $\cdot 4.545$ & 0.032 \\
\hline$B\left(\mathrm{mg} \mathrm{C} \mathrm{m} \mathrm{m}^{-3}\right)$ & 13 & 9.09 & 2.72 & 30 & 1.366 & 0.299 \\
\hline$G\left(\mu g C \mathrm{~m}^{-3} \mathrm{~h}^{-1}\right)$ & 13 & 208.15 & 93.77 & 45 & 1.812 & 0.213 \\
\hline
\end{tabular}

Less is known about feeding by other copepod species sampled in our study. The genus Oithona was first considered to be carnivorous, but is now thought to be omnivorous (Turner 1984). Information is scarce on trophic dynamics of the genus Saphirella. We found both $O$. colcarva and Saphirella had high phytoplankton clearance and ingestion rates in Chesapeake Bay (Table 2). Our measured rates of ingestion are higher for $O$. colcarva $\left[1.4 \mu \mathrm{g} \mathrm{C}(\mu \mathrm{g} \text { body } \mathrm{C})^{-1} \mathrm{~d}^{-1}\right]$ than those found by Lampitt \& Gamble (1982) for Oithona nana feeding on cultured phytoplankton $[0.05$ to $0.5 \mu \mathrm{g} \mathrm{C}$ ( $\mu \mathrm{g}$ body $C)^{-1} d^{-1}$, estimated from their Fig. 2]. From measures of respiration and ingestion, they concluded $O$. nana has unusually low metabolic and nutritional requirements. However, their experiments were conducted with a cold-water-adapted species at or near $10^{\circ} \mathrm{C}$, which is 5 to $16^{\circ} \mathrm{C}$ below the temperature range of $O$. colcarva in this study.

Information on feeding by many meroplanktonic organisms is presently restricted to descriptions of behavior. The exception for organisms occurring in our study site (although not measured by us) is bivalve larvae, which have potential filtration rates of 0.1 to $4.1 \mathrm{ml}$ ind.$^{-1} \mathrm{~d}^{-1}$ that are roughly equal to those of other planktonic taxa (Strathmann 1987. Baldwin \& Newell 1991). Information on feeding by cirripede nauplii has been inferred mostly from anatomy and observation of behavior (Strathmann 1987). The similarity in morphology in barnacle and copepod nauplii indicates similar potential feeding capabilities and the few measurements we have for cirripedes support this view ( $F$ in $\mathrm{ml}$ ind $\mathrm{s}^{-1} \mathrm{~d}^{-1}: 0.5$ to 2.0 for copepods, 1.2 for cirripedes; Table 2).

Polychaete larvae have been shown to ingest a variety of prey from diatoms (Thorson 1946) to bivalve larvae (Mileikovsky 1959), although there is little information available on their feeding rates (Strathmann 1987). The temporal coincidence of polychaete larval abundance with the chlorophyll peak in the mesohaline bay suggests a reliance of the larvae on this food resource. Our observation that polychaete larvae had the highest filtration and ingestion rates on phytoplankton of any non-copepod group supports a potential link between polychaete production and timing of the spring bloom.

Results of the analysis of variance for Acartia sp. copepods in surface waters are important because they indicate which parameters: (1) showed significant differences over time, and (2) were highly variable at all time scales and therefore deserve intensive sampling in future efforts. Filtration and ingestion rates showed significant differences between sampling periods (Table 4) as did temperature, which was positively correlated with both rates. Chlorophyll was not significantly different between dates, and showed relatively low variation throughout the study. The observation that Acartia biomass was highly variable in surface waters and showed no significant difference between sample dates may have been caused by horizontal patchiness or vertical migration in and out of the surface (Roman et al. 1988b). The standard error of average Acartia biomass was $30 \%$ and probably contributed most to the high standard error $(45 \%)$ found for grazing rate $(G=I \times B)$. Therefore, aside from variability inherent to particular experimental methods and given a relatively constant and generous food supply, variations in feeding rate measurements are constrained by organisms' physiology and necessarily related to temperature. Biomass on the other hand is difficult to estimate accurately because of vertical and horizontal patchiness and because it represents an integrated response of the zooplankton population to previous conditions in the water column. These factors should be considered in any comparison of grazing and primary production rates.

During the March 1988 sampling date, the measured zooplankton community had the potential to remove all daily primary production occurring at the mid-bay station. Nonetheless, a large standing stock of chlorophyll existed at the station (Table 3 ). This could result from temporal or spatial heterogeneity in the distribution of phytoplankton and zooplankton at our sampling 
site. Prior to our cruise date, primary production may have been higher than measured, while zooplankton stocks may have been lower, allowing phytoplankton biomass to accumulate at the station. However, zooplankton stocks have been historically high at this site in March (Brownlee \& Jacobs 1987, Olson 1987), and phytoplankton production (439 $\mathrm{mg} \mathrm{C} \mathrm{m}^{-2}$ ) was near the predicted seasonal pattern in the bay (Malone et al. 1988).

Alternatively, phytoplankton produced elsewhere may be advected laterally from the flanks to the center of the bay (Malone et al. 1986), or from up-bay in surface waters or down-bay at depth due to net estuarine circulation (Tyler \& Seliger 1978, Malone et al. 1988). Brownlee \& Jacobs (1987) found during 1985 that the peak in zooplankton biomass moved down bay with time, starting in freshwater near the bay head in January and occurring in the mesohaline region in March. A similar pattern may occur for phytoplankton biomass as the turbidity maximum moves down the Chesapeake Bay with the spring freshet (Fisher et al. 1988). In other grazing studies, Tiselius (1988) found that the copepod community ( $>200 \mu \mathrm{m}$ ) in the Skagerrak and Kattegat removed less than $4 \%$ of the phytoplankton standing stock but up to $48 \%$ of the daily primary production between May and October and attributed the large standing stock to variations in phytoplankton quality. Therefore, the existence of large standing stocks of chlorophyll in the water column may occur as a result of advection or because the phytoplankton consists mostly of small, dying, or unpalatable cells which are 'unavailable' or 'undesirable' to zooplankton.

Our results for the grazing impact of zooplankton in Chesapeake Bay are summarized in Table 5. Compared to Heinle's (1974) values for Acartia tonsa in the Patuxent River, we found rates of phytoplankton removal by the whole community $(>200 \mu \mathrm{m}) 2$ to 3 times higher in the mainstem of the bay. By examining only $A$. tonsa, Heinle may have underestimated potential grazer biomass in the Patuxent, or the greater depth at our bay station may provide refuge for a larger depth integrated standing stock of zooplankton.

Our results indicate that except in March, half or more of the primary production occurring at the midbay station during this study was not consumed by large zooplankton. Dagg \& Turner (1982) predicted that $50 \%$ of the primary production on Georges Bank escaped grazing by net zooplankton (>102 $\mu \mathrm{m}$ ), while Welschmeyer \& Lorenzen (1985) found only 23 to $39 \%$ of the annual chlorophyll production was not grazed by large zooplankton that produce sinking fecal pellets in a North American fjord. The relatively low metazoan grazing pressure reported here may result from the generally high rates of primary production occuring in Chesapeake Bay relative to other coastal areas studied.

Sellner et al. (1987) estimated that potential microzooplankton grazing of primary production was greater in the mesohaline Chesapeake Bay during August ( 21 to $153 \%$ ) compared with May (13 to $55 \%$ ) (Table 4). This compares with results from Gifford (1988) who found microzooplankton grazing could remove up to $100 \%$ of the primary production in Halifax Harbour $(0 \%$ when diatoms were abundant), and Capriulo \& Carpenter (1980) who found that tintinnid ciliates could remove between 12 and $27 \%$ daily of phytoplankton standing stock from Long Island Sound in June and November respectively. A combination of our data with those of Sellner et al. (1987) shows that the maximum combined impact of grazers occurs during March and August (Table 5). In May and October, the bulk of the local primary production is unutilized by grazers and may be available for lateral (down bay) or vertical (to benthos) export.

Our results indicate that in the mesohaline Chesapeake Bay, individual zooplankton feeding rates are generally related to temperature, and that estimates of community grazing are most sensitive to accurate measurements of zooplankton biomass. We have shown that grazing by taxonomic groups generally neglected in previous studies, such as copepod

Table 5. Estimated percentage of daily primary production grazed by zooplankton during 4 cruises to mesohaline Chesapeake Bay during 1988 and comparison with other studies

\begin{tabular}{|c|c|c|c|c|c|}
\hline Size fraction & March & May & August & October & Source \\
\hline$>200 \mu \mathrm{m}$ & - & 3.3 & 10.2 & - & Heinle (1974) \\
\hline$>200 \mu \mathrm{m}$ & 84.3 & 7.7 & 25.6 & 16.7 & \\
\hline $64-200 \mu \mathrm{m}$ (metazoan) & 27.7 & 7.6 & 26.4 & 7.5 & This study \\
\hline Total & 112 & 15.3 & 52 & 24.4 & \\
\hline $20-200 \mu \mathrm{m}$ & - & $13-55$ & $21-153$ & - & Sellner (1987) \\
\hline Primary production available for export & $0 ?$ & $30-72$ & $0-27$ & $<76 ?$ & \\
\hline
\end{tabular}


nauplii, polychaete larvae and cyclopoid copepods, can remove significant amounts of phytoplankton (but see Paffenhöfer 1971, Dagg \& Turner 1982). The total amount of primary production removed by zooplankton in Chesapeake Bay varied between sampling periods and may have been related to changes in zooplankton community structure. The observed temporal changes in grazing pressure by metazoan zooplankton should alter the amount of food resources available for protozoan zooplankton and for export out of the system.

Acknowledgements. This work was completed as part of a larger study examining the effects of anoxia on living resources in Chesapeake Bay. We thank T. Malone for temperature, particulate carbon, algal pigment and primary productivity data. Indispensable shipboard assistance was provided by A. Gauzens, J. Jensen, C. Miller, S. Pike and B. Wendler. The captain and crew of the RV 'Aquarius' provided effective support at sea. We also thank M. Dagg, H. Ducklow, M. Kemp, T. Malone, and several anonymous reviewers whose constructive comments improved earlier versions of the manuscript. This research was supported by a grant from NOAAA/Sea Grant to M. Roman. CEES contribution no. 2330.

\section{LITERATURE CITED}

Balch, W. M. (1985). Lack of an effect of light on methylamine uptake by phytoplankton. Limnol. Oceanogr. 30: 665-674

Baldwin, B. S., Newell, R. I. E. (1991). Omnivorous feeding by planktotrophic larvae of the eastern oyster Crassostrea virginica. Mar. Ecol. Prog. Ser. 78: 285-301

Banse, K. (1982). Mass-scaled rates of respiration and intrinsic growth in very small invertebrates. Mar. Ecol. Prog. Ser. 9: 281-297

Barthel, K.-G. (1983). Food uptake and growth efficiency of Eurytemora affinis. Mar. Biol. 74: 269-274

Bartram, W. C. (1980). Experimental development of a model for feeding of neritic copepods on phytoplankton. J. Plankton Res. 3: 25-51

Berggreen, U., Hansen, B., Kiørboe, T. (1988). Food size spectra, ingestion and growth of the copepod Acartia tonsa during development: implications for determination of copepod production. Mar. Biol. 99: 341-352

Bishop, J. K., Conte, M. H., Weibe, P. H., Roman, M. R., Langdon, C. (1986). Particulate matter production and consumption in deep mixed layers: observations in a warm core ring. Deep Sea Res. 33: 1813-1841.

Boyd, C. M., Smith, S. L., Cowles, T J. (1980). Grazing patterns of copepods in the upwelling off Peru. Limnol. Oceanogr. 25: 583-596

Brownlee, D. C., Jacobs, F. (1987). Mesozooplankton and microzooplankton in the Chesapeake Bay. In: Majumdar, S. K., Hall, L. V. Jr, Austin, H. M. (eds.) Contaminant problems and management of living Chesapeake Bay resources. The Pennsylvania Academy of Science, Philadelphia, p. 217-269

Capriulo, G. M., Carpenter, E. J. (1980). Grazing by 35 to $202 \mu \mathrm{m}$ micro-zooplankton in Long Island Sound. Mar. Biol. 56: 319-326

Conover, R. J. (1956). Oceanography of Long Island Sound, 1952-1954: biology of Acartia clausi and A. tonsa. Bull. Bingham Oceanogr. Coll. 15: 156-233
Dagg, M. J. (1985). The effects of food limitation on diel migratory behavior in marine zooplankton. Arch. Hydrobiol. Beih. 21. 247-255

Dagg, M. J., Grill, D. W. (1980). Natural feeding rates of Centropages typicus females in the New York Bight. Limnol. Oceanogr. 25: 597-609

Dagg, M. J., Turner, J. T (1982). The impact of copepod grazing on the phytoplankton of Georges Bank and the New York Bight. Can. J. Fish. Aquat. Sci. 39: 979-990

Daro, M. H. (1978). A simplified ${ }^{14} \mathrm{C}$ method for grazing measurements on natural planktonic populations. Helgoländer wiss. Meeresunters. 31: 241-248

Daro, M. H. (1980). Field study of the diel feeding of a population of Calanus finmarchicus at the end of a phytoplankton bloom, FLEX '76, 22 May 5 June. Meteor Forsch.Ergeb. Reihe A, No. 22: 123-132

Fisher, T. R., Harding, L. W. Jr, Stanley, D. W., Ward, L. G (1988). Phytoplankton, nutrients, and turbidity in the Chesapeake, Delaware, and Hudson estuaries. Estuar coast. Shelf Sci. 27:61-93

Fernández, F. (1979). Nutrition studies in the nauplius larva of Calanus pacificus (Copepoda: Calanioda). Mar. Biol. 53 $131-147$

Gifford, D. J. (1988). Impact of grazing by microzooplankton. in the northwest arm of Halifax Harbour, Nova Scotia. Mar. Ecol. Prog. Ser. 47: 249-258

Gifford. D. J., Dagg, M. J. (1988). Feeding of the estuarine copepod Acartia tonsa Dana: carnivory vs herbivory in natural microplankton assemblages. Bull. mar. Res. 43: 458-468

Heinje, D. R. (1966). Production of a calanoid copepod, Acartia tonsa, in the Patuxant River Estuary. Chesapeake Sci. $7: 59-74$

Heinle, D. R. (1969). Temperature and zooplankton. Chesapeake Sci. 10: 186-209

Heinle, D. R. (1974). An alternate grazing hypothesis for the Patuxent Estuary. Chesapeake Sci. 15: 146-150

Heinle, D. R., Flemer, D. A. (1975). Carbon requirements of a population of the estuarine copepod Eurytemora affinis. Mar. Biol. 31: 235-247

Ikeda, T. (1974). Nutritional ecology of zooplankton. Mem. Fac. Fish. Hokkaido Univ. 22: 1-97

Lacalli, T. C. (1981). Annual spawning cycles and planktonic larvae of benthic invertebrates from Passamaquoddy Bay, New Brunswick. Can. J. Zool. 59: 433-440

Lampitt, R. S., Gamble, J. C. (1982). Diet and respiration of the small planktonic marine copepod Oithona nana. Mar. Biol. 66: 185-190

Malone, T. C., Kemp, W. M., Ducklow, H. W., Boynton, W. R., Tuttle, J. H., Jonas, R. B. (1986). Lateral variation in the production and fate of phytoplankton in a partially stratified estuary. Mar. Ecol. Prog. Ser. 32: 149-160

Malone, T. C., Crocker, L. H., Pike, S. E., Wendler, B. W. (1988). Influence of river flow on the dynamics of phytoplankton production in a partially stratified estuary. Mar. Ecol. Prog. Ser. 48: 235-249

Malone. T. C., Ducklow H. W. (1990). Microbial biomass in the coastal plume of Chesapeake Bay: phytoplanktonbacterioplankton relationships. Limnol. Oceanogr. 35: $296-312$

Mileikovsky, S. A. (1959). Interrelations between the pelagic larvae of Nephthys cillata (O. F. Müller), Macoma baltica and Mya arenaria of the White Sea. Zool. Zh. 38: 1889-1891

Nicolajsen, H., Mohlenberg, F., Kiorboe, T (1983). Algal grazing by the planktonic copepods Centropages hamatus and Pseudocalanus sp.: diurnal and seasonal variation during the spring phytoplankton bloom in the Oresund. Ophelia 22: $15-31$ 
Nival, P., Nival, S. (1976). Particle retention efficiencies of an herbivorous copepod, Acartia clausi (adult and copepodite stages): effects on grazing. Limnol. Oceanogr. 21: 24-38

Olson, M. M. (1987). Zooplankton. In: Heck, K. L. Jr (ed.) Ecological studies in the middle reach of Chesapeake Bay. 23. Lecture notes on coastal and estuarine studies. Springer-Verlag, New York, p. 38-81

Paffenhöfer, G.-A. (1971). Grazing and ingestion rates of nauplii, copepodites and adults of the marine planktonic copepod Calanus helgolandicus. Mar. Biol. 11: 286-298

Parsons, T R., Maita, Y., Lalli, C. M. (1984). A manual of chemical and biological methods for seawater analysis Pergamon Press, New York

Roman, M. R. (1984). Utilization of detritus by the copepod Acartia tonsa. Limnol. Oceanogr. 24: 949-959

Roman, M. R., Rublee, P. A. (1981). A method to measure in situ zooplankton grazing rates on natural particle assemblages. Mar. Biol. 65: 303-309

Roman, M. R., Ashton, C. A., Gauzens, A. L. (1988a). Day/ night differences in the grazing impact of marine copepods. Hydrobiolgia 167/168: 21-30

Roman, M. R., Malone, T. C., White, J. R. (1988b). Short-term variations in phytoplankton-zooplankton interactions in Chesapeake Bay. EOS 69: 1097

Sellner, K. G., Brownlee, D. C., Harding, L. W. Jr (1987). Implications of microzooplankton grazing on carbon flux and anoxia in Chesapeake Bay. In: Mackiernan, G. B. (ed.) Dissolved oxygen in Chesapeake Bay, processes and effects. Publication \#:UM-SG-TS-87-03, Maryland Sea Grant, College Park, Maryland, p. 86-90

Starr, M., Himmelman, J. H., Therriault, J. C. (1990). Direct coupling of marine invertebrate spawning with phytoplankton blooms. Science 247: 1071-1074

Stearns, D. E. (1986). Copepod grazing behavior in simulated natural light and its relation to nocturnal feeding. Mar. Ecol. Prog. Ser. 30: 65-76

Stearns, D. E., Litaker, W., Rosenberg, G. (1987). Impacts of zooplankton grazing and excretion on short interval fluctuations in chlorophyll $a$ and nitrogen concentrations in a well-mixed estuary. Estuar. coast. Shelf Sci. 24: 305-325

Stoecker, D. K., Egloff, D. A. (1987). Predation by Acartia tonsa Dana on planktonic ciliates and rotifers. J. exp. mar. Biol. Ecol. 110: 53-68

Strathmann, R. R. (1987). Larval feeding. In: Giese, A. C., Pearse, J. S., Pearse, V. B. (eds.) Reproduction of marine

This article was presented by K. R. Tenore, Solomons, Maryland, USA invertebrates, Vol. IX. General aspects: seeking unity in diversity. Blackwell Scientific Publications, Palo Alto, p. $465-533$

Tester, P. A., Turner, J. T. (1988). Comparative carbon-specific ingestion rates of phytoplankton by Acartia tonsa, Centropages velificatus and Eucalanus pileatus grazing on natural phytoplankton assemblages in the plume of the Mississippi River (northern Gulf of Mexico continental shelf). Hydrobiologia 167/168: 211-217

Thorson, G. (1946). Reproduction and larval development of Danish marine bottom invertebrates with special reference to planktonic larvae in the Sound (Oresund). Meddr Komm. Danm. Fisk.- og Havunders. (Ser. Plankton) 4: $1-523$

Tiselius, P. (1988). Effects of diurnal feeding rhythms, species composition and vertical migration on the grazing impact of calanoid copepods in the Skagerrak and Kattegat. Ophelia 28: 215-230

Turner, J. T. (1984). The feeding ecology of some zooplankters that are important prey items of larval fish. NOAA Tech. Rep. NMFS 7

Tyler, M. A., Seliger, H. H. (1978). Annual subsurface transport of a red tide dinoflagellate to its bloom area: water circulation patterns and organism distributions in the Chesapeake Bay. Limnol. Oceanogr. 23: 227-246

Welschmeyer, N. A., Lorenzen, C. J. (1985). Role of herbivory in controlling phytoplankton abundance: annual pigment buget for a temperate marine fjord. Mar. Biol. 90: $75-86$

White, J. R., Roman, M. R. (1991). Measurement of zooplankton grazing using particles labelled in light and dark with [methyl- ${ }^{3} \mathrm{H}$ ]methylamine hydrochloride. Mar. Ecol. Prog. Ser. 71: 45-52

White, J. R., Roman, M. R. (1992). Egg production by the calanoid copepod Acartia tonsa in the mesohaline Chesapeake Bay: the importance of food resources and temperature. Mar. Ecol. Prog. Ser. 86: 239-249

Wiebe, P. H., Boyd, S., Cox, J. L. (1975). Relationships between zooplankton displacement volume, wet weight, and carbon. Fish. Bull. U.S. 73: 777-786

Young, C. M., Chia, F. S. (1987). Larval feeding. In: Giese, A. C., Pearse, J. S., Pearse, V. B. (eds.) Reproduction of marine invertebrates, Vol. IX General aspects: seeking unity in diversity. Blackwell Scientific Publications, Palo Alto, p. 385-442

Manuscript first received: July 18, 1991

Revised version accepted: June 23, 1992 